\title{
INFLUENCE OF BATH TEMPERATURE AND PH VALUE ON PROPERTIES OF CHEMICALLY DEPOSITED $\mathrm{CU}_{4} \mathrm{SNS}_{4}$ THIN FILMS
}

\author{
ANUAR KASSIM ${ }^{1, *}$, TAN WEE TEE ${ }^{1}$, ATAN MOHD. SHARIF ${ }^{1}$, DZULKEFLY KUANG ABDULLAH ${ }^{1}$, MD. JELAS \\ HARON ${ }^{1}$, HO SOON MIN ${ }^{1}$ AND NAGALINGAM SARAVANAN ${ }^{2}$
}

\author{
${ }^{1}$ Department of Chemistry, Faculty of Science, Universiti Putra Malaysia, 43400 Serdang, \\ Selangor, Malaysia. \\ ${ }^{2}$ Department of Bioscience and Chemistry, Faculty of Engineering and Science, Universiti \\ Tunku Abdul Rahman, 53300 Kuala Lumpur, Malaysia. \\ (Received: December 31, 2008 - Accepted: May 27, 2009)
}

\begin{abstract}
Thin films of $\mathrm{Cu}_{4} \mathrm{SnS}_{4}$ semiconductors were prepared by chemical bath deposition technique in aqueous solutions. The effects of various bath temperatures $\left(40,50\right.$ and $\left.60^{\circ} \mathrm{C}\right)$ and $\mathrm{pH}$ values $(\mathrm{pH} 0.5, \mathrm{pH} 1.0$ and $\mathrm{pH} 1.5)$ on growth of films were reported. The structure and morphology characteristics of thin films of $\mathrm{Cu}_{4} \mathrm{SnS}_{4}$ grown on indium tin oxide glass substrates were investigated by X-ray diffraction and atomic force microscopy techniques. The optical properties were measured to determine the transition type and band gap value. The thin films produced were found to be polycrystalline with orthorhombic structure. The X-ray diffraction data showed that the most intense peak at $2 \theta=30.2^{\circ}$ which belongs to (221) plane of $\mathrm{Cu}_{4} \mathrm{SnS}_{4}$. The films deposited at $50{ }^{\circ} \mathrm{C}$ were found to have the best photoresponse activity and smaller crystal size. At pH 1.5, the film showed well-covered entire substrate surface and the highest absorption values in AFM and optical study, respectively. The best condition to prepare good quality thin films can be carried out at $50{ }^{\circ} \mathrm{C}$ with $\mathrm{pH} 1.5$. The bandgap value was found to be $1.4 \mathrm{eV}$ with direct transition.
\end{abstract}

Keywords: Semiconductor, thin films, band gap, chemical bath deposition

\section{INTRODUCTION}

Interest on the preparation and study of physical properties of ternary chalcogenide compounds for their possible applications in optoelectronic devices, solar cells, infrared detectors and light emitting diodes has been increasing in the recent years. There are many techniques for preparing thin films such as plasma-enhanced chemical vapor deposition, ${ }^{1}$ metal organic chemical vapor deposition, ${ }^{2}$ thermal evaporation, ${ }^{3}$ chemical bath deposition, ${ }^{4}$ close spaced sublimation, ${ }^{5}$ vacuum evaporation, ${ }^{6}$ electrodeposition, ${ }^{7}$ molecular beam epitaxy, ${ }^{8}$ spray pyrolysis ${ }^{9}$ and sputter deposition ${ }^{10}$. Amongst these deposition techniques, chemical bath deposition is most commonly used because it is a simple, cost effective and convenient for larger area deposition of thin films. The chemical bath deposition method has been proved as a suitable method of preparing binary compounds like $\mathrm{MnS},{ }^{11} \mathrm{SnS},{ }^{12} \mathrm{SnSe},{ }^{13} \mathrm{CdSe},{ }^{14} \mathrm{Sb}_{2} \mathrm{~S}_{3},{ }^{15}$ $\mathrm{PbS}^{16}$ and ternary semiconductors such as $\mathrm{CdSSe},{ }^{17} \mathrm{CuInSe}_{2},{ }^{18} \mathrm{Cd}_{0.5} \mathrm{Zn}_{0.5} \mathrm{Se}^{19}$ and $\mathrm{CuBiS}_{2}{ }^{20}$.

Here, we report the preparation and characterization of $\mathrm{Cu}_{4} \mathrm{SnS}_{4}$ thin films by chemical bath deposition. The effects of $\mathrm{pH}$ and bath temperatures on the properties of these films are investigated. The structure of the film was studied by X-ray diffraction. The morphology and optical absorption properties were determined by using atomic force microscope and UV-Visible Spectrophotometer, respectively.

\section{EXPERIMENTAL}

All the chemicals used for the deposition were analytical grade. It includes copper sulfate $\left(\mathrm{CuSO}_{4}\right)$, tin chloride $\left(\mathrm{SnCl}_{2}\right)$, sodium thiosulfate $\left(\mathrm{Na}_{2} \mathrm{~S}_{2} \mathrm{O}_{3}\right)$, disodium ethylenediaminetetraacetic acid ( $\mathrm{Na}_{2}$ EDTA) and hydrochloric acid $(\mathrm{HCl})$. All the solutions were prepared in deionised water (Alpha-Q Millipore). $10 \mathrm{ml}$ of $\mathrm{CuSO}_{4}(0.05 \mathrm{M})$ solution was added into $10 \mathrm{ml}$ of $\mathrm{SnCl}_{2}(0.05 \mathrm{M})$ solution in $100 \mathrm{ml}$ beaker. To it, $10 \mathrm{ml}$ of $\mathrm{Na}_{2} \operatorname{EDTA}(0.1 \mathrm{M})$ solution was added and then solution was continuously stirred. $10 \mathrm{ml}$ of $\mathrm{Na}_{2} \mathrm{~S}_{2} \mathrm{O}_{3}(0.05 \mathrm{M})$ solution was then added into a beaker slowly. The resultant solution was stirred for few minutes. The indium doped tin oxide (ITO) glass was used as the substrate. The ultrasonically cleaned glass substrates were immersed vertically into acidic bath. In order to determine the optimum condition for the deposition process, the films were deposited at different bath temperatures $\left(40-60^{\circ} \mathrm{C}\right)$ and $\mathrm{pH}$ values ( $\mathrm{pH} 0.5$ to $\mathrm{pH} 1.5)$. During deposition period the beaker was kept undisturbed. The substrates were removed from the baths after 2 hours. The deposited films were tested for adhesion by subjecting it to a steady stream of distilled water.

X-ray diffraction analysis was carried out, using a Philips PM 11730 diffractometer for the $2 \theta$ ranging from $20^{\circ}$ to $60^{\circ}$ with $\mathrm{CuK}_{\alpha}(\lambda=1.5418 \AA)$ radiation. Topography was measured by using an atomic force microscopy (Quesant Instrument Corporation, Q-Scope 250) operating in contact mode, with $\mathrm{Si}_{3} \mathrm{~N}_{4}$ cantilever. Photoelectrochemical (PEC) experiments were performed using a $[\mathrm{Fe}(\mathrm{CN})]_{6}^{3-} /[\mathrm{Fe}(\mathrm{CN})]^{4-}$ redox system, by performing linear sweep voltammetry between -500 to $-1000 \mathrm{mV}$ at a sweep rate of $10 \mathrm{mV} / \mathrm{s}$. The $\mathrm{Ag} / \mathrm{AgCl}$ electrode and platinum wire were used as reference electrode and counter electrode, respectively. The sequence of constant illumination and dark period were performed on the PEC cell to study the effect on photoactivity behavior. A halogen lamp $(300 \mathrm{~W}, 120 \mathrm{~V})$ was used for illuminating the electrode. Optical absorption study was carried out using the Perkin Elmer UV/ Vis Lambda 20 Spectrophotometer. The film-coated indium doped tin oxide glass was placed across the sample radiation pathway while the uncoated ITO glass was put across the reference path. The absorption data were manipulated for the determination of the band gap energy, $\mathrm{E}_{\mathrm{g}}$.

\section{RESULTS AND DISCUSSION}

Fig. 1 shows the XRD patterns of the films deposited at $\mathrm{pH} 1.2$ at different chemical bath temperatures. All the samples showed a polycrystalline in nature. The patterns displayed diffraction peak at $2 \theta=21.2^{\circ}$ which corresponds to (211) plane of indium tin oxide substrate for all samples. There are seven peaks occurred at $2 \theta=28.6^{\circ}, 30.1^{\circ}, 35.2^{\circ}, 38.8^{\circ}, 42.9^{\circ}, 47.2^{\circ}$ and $50.6^{\circ}$ were detected for the films deposited at 40,50 and $60{ }^{\circ} \mathrm{C}$ respectively. The corresponding $d$-spacing values are well in agreement with JCPDS data (Reference code: 010710129) of 3.12, 2.96, 2.54, 2.30, 2.10, 1.92 and $1.80 \AA$ which attributed to the (102), (221), (420), (222), (331), (040) and (711) planes, respectively. All these peaks are related to the compound of $\mathrm{Cu}_{4} \mathrm{SnS}_{4}$ of orthorhombic structure $\left(\mathrm{a}=13.5580 \AA, \mathrm{b}=7.6810 \AA, \mathrm{c}=6.4120 \AA, \alpha=\beta=\gamma=90^{\circ}\right)$. As the chemical bath temperature is increased from $50{ }^{\circ} \mathrm{C}$ to $60{ }^{\circ} \mathrm{C}$, the intensity of diffraction peak (221) decreases and this peak becomes boarder indicating poor crystallinity of the sample. 


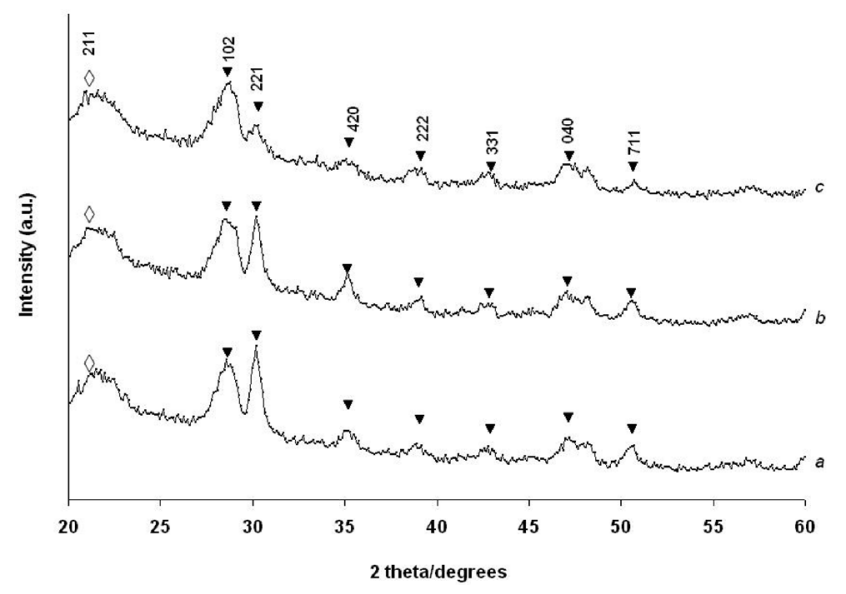

Fig. 1. X-ray diffraction patterns of $\mathrm{Cu}_{4} \mathrm{SnS}_{4}$ films deposited at different chemical bath temperatures. [(a) $40{ }^{\circ} \mathrm{C}$ (b) $50{ }^{\circ} \mathrm{C}$ (c) $\left.60{ }^{\circ} \mathrm{C}\right]\left(\boldsymbol{\nabla C u}_{4} \mathrm{SnS}_{4} \diamond\right.$ indium tin oxide substrate).

Fig. 2 shows the three-dimensional representation of $20 \mu \mathrm{m}$ X $20 \mu \mathrm{m}$ area of the $\mathrm{Cu}_{4} \mathrm{SnS}_{4}$ films deposited at different chemical bath temperatures. Fewer grains are visible for the films deposited at $40{ }^{\circ} \mathrm{C}$ and $60{ }^{\circ} \mathrm{C}$ (Fig. 2a, 2c). The grains were distributed randomly over the surface of substrate. The sizes of the grains exhibited randomly random orientation as it varies from one to another. This revealed that the thicker surface coverage of the $\mathrm{Cu}_{4} \mathrm{SnS}_{4}$ onto the substrate. However, the grains were found to be fine and distributed evenly over the substrate surface for the film deposited at $50{ }^{\circ} \mathrm{C}$ (Fig. 2b). The AFM image of this film indicated complete sample coverage over the substrate and smooth $\mathrm{Cu}_{4} \mathrm{SnS}_{4}$ texture.

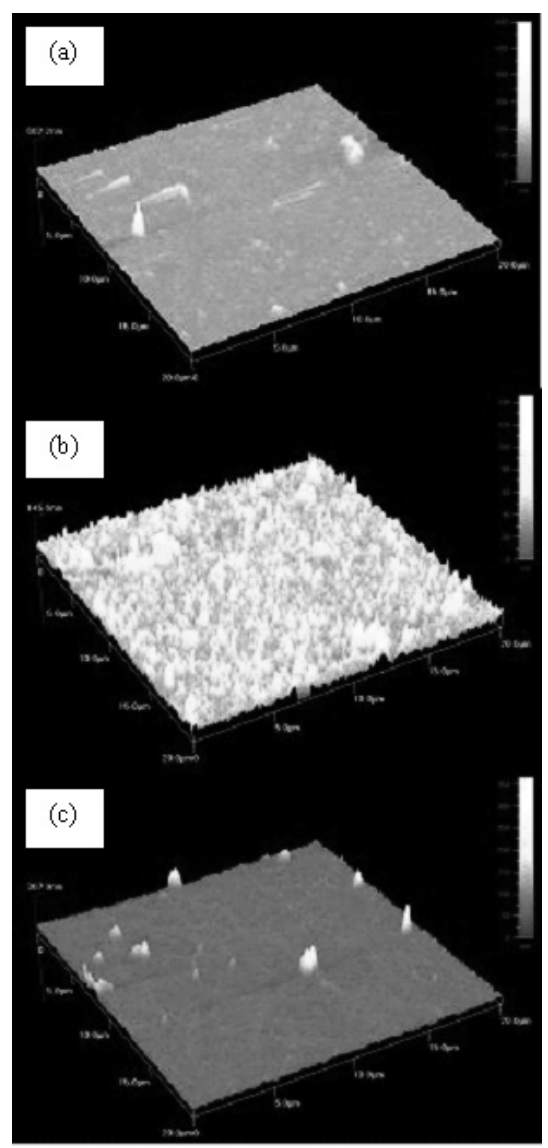

Fig. 2. Atomic force microscopy images of $\mathrm{Cu}_{4} \mathrm{SnS}_{4}$ films deposited at different chemical bath temperatures $\left[\left(\right.\right.$ a) $40{ }^{\circ} \mathrm{C}$ (b) $50^{\circ} \mathrm{C}$ (c) $\left.60{ }^{\circ} \mathrm{C}\right]$.
Fig. 3 shows the absorption spectra of $\mathrm{Cu}_{4} \mathrm{SnS}_{4}$ films at various bath temperatures. The $\mathrm{Cu}_{4} \mathrm{SnS}_{4}$ thin films show a gradually increasing absorbance throughout the visible region, which makes it possible for this material to be used in a photoelectrochemical cell. From the absorption spectra, it was observed that there is no significant change of spectra, indicating thinner samples obtained. The thickness of thin films deposited at $40^{\circ}, 50^{\circ}$ and 60 ${ }^{\circ} \mathrm{C}$ were 602, 145 and $368 \mathrm{~nm}$, respectively. However, higher absorption characteristic could be obtained for the film deposited at $50{ }^{\circ} \mathrm{C}$ as compared with other temperatures. Thus, this bath temperature is more preferable in the preparation of $\mathrm{Cu}_{4} \mathrm{SnS}_{4}$ films of better quality on ITO substrate.

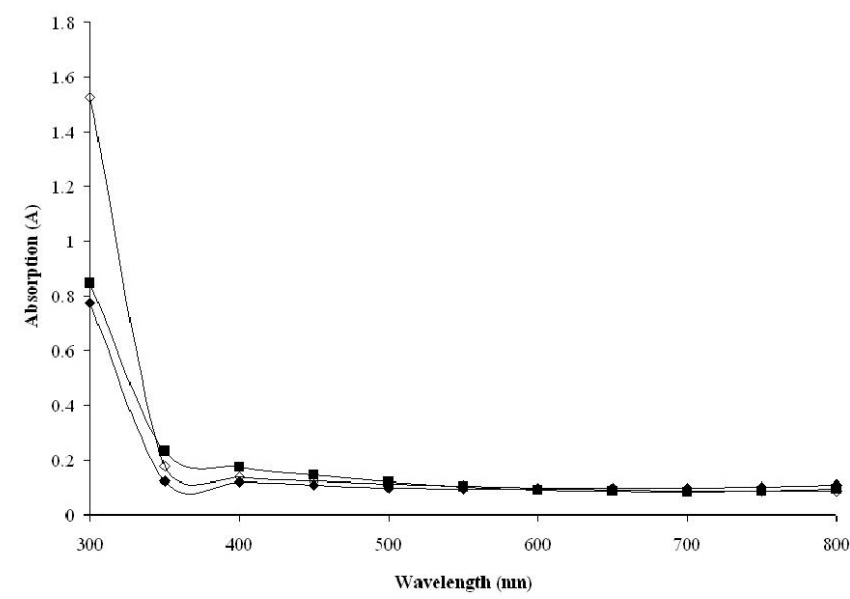

Fig. 3. Optical absorbance versus wavelength of the $\mathrm{Cu}_{4} \mathrm{SnS}_{4}$ films deposited at different chemical bath temperatures $\left(\diamond 40^{\circ} \mathrm{C} ; \diamond 50^{\circ} \mathrm{C} ;-60^{\circ} \mathrm{C}\right)$.

Fig. 4 shows the different between photocurrent $\left(I_{p}\right)$ and darkcurrent (I ) for the films deposited at different chemical bath temperatures. The film deposited at $50{ }^{\circ} \mathrm{C}$ showed the highest photoresponse activity if compared with other deposition temperatures. This could be due to sufficient semiconducting material deposited onto the surface of substrate. The photocurrent occurs on the negative potential indicates the films are p-type and they can be deployed as a photocathode in a photoelectrochemical cell for reduction reactions.

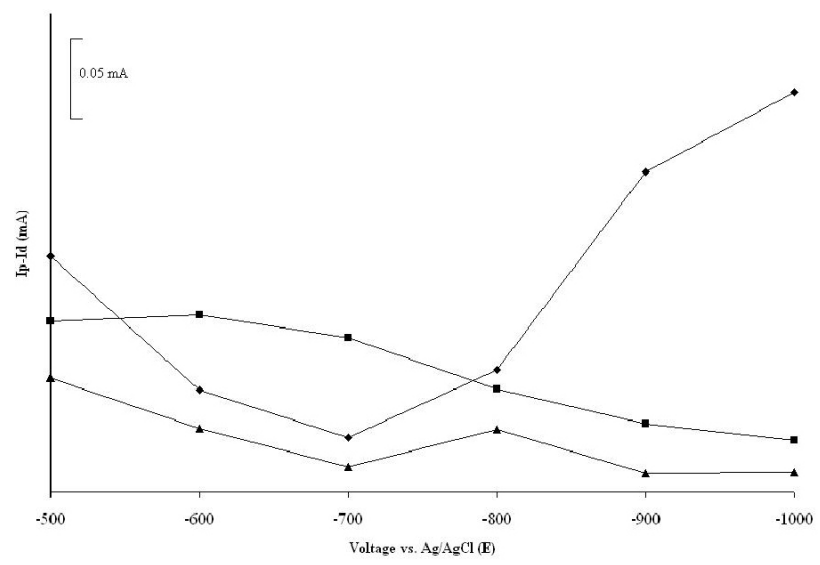

Fig. 4. Comparison of photosensitivity of the films deposited at different chemical bath temperatures $\left(\Delta 40^{\circ} \mathrm{C} ; 500^{\circ} \mathrm{C}\right.$; $\left.60{ }^{\circ} \mathrm{C}\right)$.

Fig. 5 shows the XRD patterns of $\mathrm{Cu}_{4} \mathrm{SnS}_{4}$ thin films deposited at $50{ }^{\circ} \mathrm{C}$ at different $\mathrm{pH}$ ranging from $\mathrm{pH} 0.5$ to $\mathrm{pH} 1.5$. The XRD patterns are found to be polycrystalline with orthorhombic structure. There are two peaks can be observed at diffraction angles of $30.3^{\circ}$ and $50.6^{\circ}$ on the XRD pattern obtained on the films prepared at $\mathrm{pH} 0.5$. These two peaks are assigned to interplanar distances of 2.95 and $1.81 \AA$ which corresponding to (221) and (711) planes respectively. When the $\mathrm{pH}$ value was increased from $\mathrm{pH} 0.5$ to $\mathrm{pH} 1$ and 1.5 , the number of peaks related with $\mathrm{Cu}_{4} \mathrm{SnS}_{4}$ formation increased. There are five additional $\mathrm{Cu}_{4} \mathrm{SnS}_{4}$ peaks could be detected at $2 \theta=28.6^{\circ}, 35.1^{\circ}, 38.7^{\circ}, 42.7^{\circ}$ 
and $47.1^{\circ}$ which attributed to the (102), (420), (222), (331) and (040) planes. On the other hand, the XRD pattern displayed diffraction peak at $2 \theta=21.3^{\circ}$ which corresponds to (211) plane of indium tin oxide substrate for thin film deposited at $\mathrm{pH} 1$.

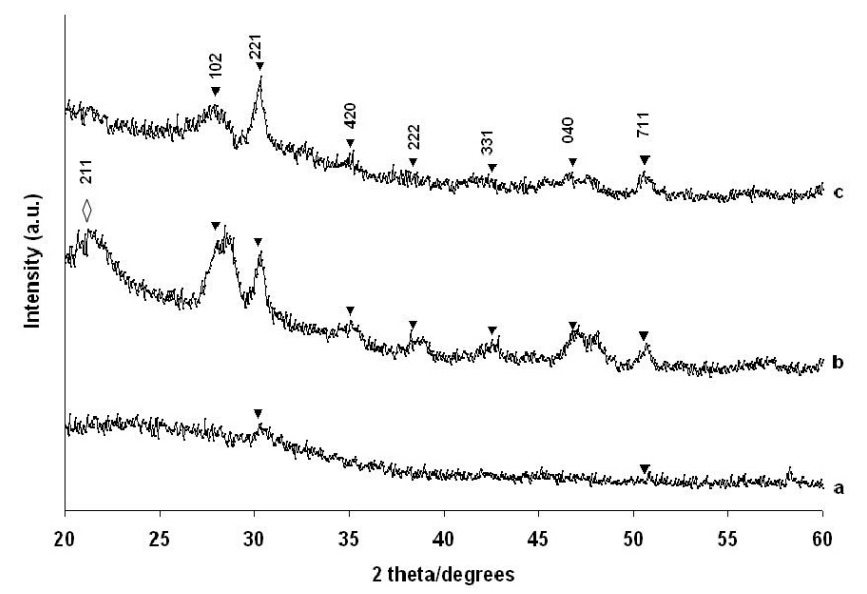

Fig.5. X-ray diffraction patterns of $\mathrm{Cu}_{4} \mathrm{SnS}_{4}$ thin films deposited at $50{ }^{\circ} \mathrm{C}$ in different $\mathrm{pH}$ solutions (a) $\mathrm{pH} 0.5$ (b) $\mathrm{pH} 1.0$ (c) $\mathrm{pH} 1.5\left(\boldsymbol{\nabla} \mathrm{Cu}_{4} \mathrm{SnS}_{4} \diamond\right.$ indium tin oxide substrate)

Fig. 6 shows the three-dimensional representation of a $20 \mu \mathrm{m} \mathrm{X} 20 \mu \mathrm{m}$ area of the $\mathrm{Cu}_{4} \mathrm{SnS}_{4}$ thin films deposited at different $\mathrm{pH}$ of the chemical bath. The irregular surface of film and discontinuous distribution of grains was detected for the film grown at $\mathrm{pH} 0.5$ (Fig. 6a) and $\mathrm{pH} 1$ (Fig. 6b) respectively. However, the film shows uniform, dense and well-covered entire substrate surface (Fig. 6c) when the solution $\mathrm{pH}$ is increased from 1 to 1.5 .

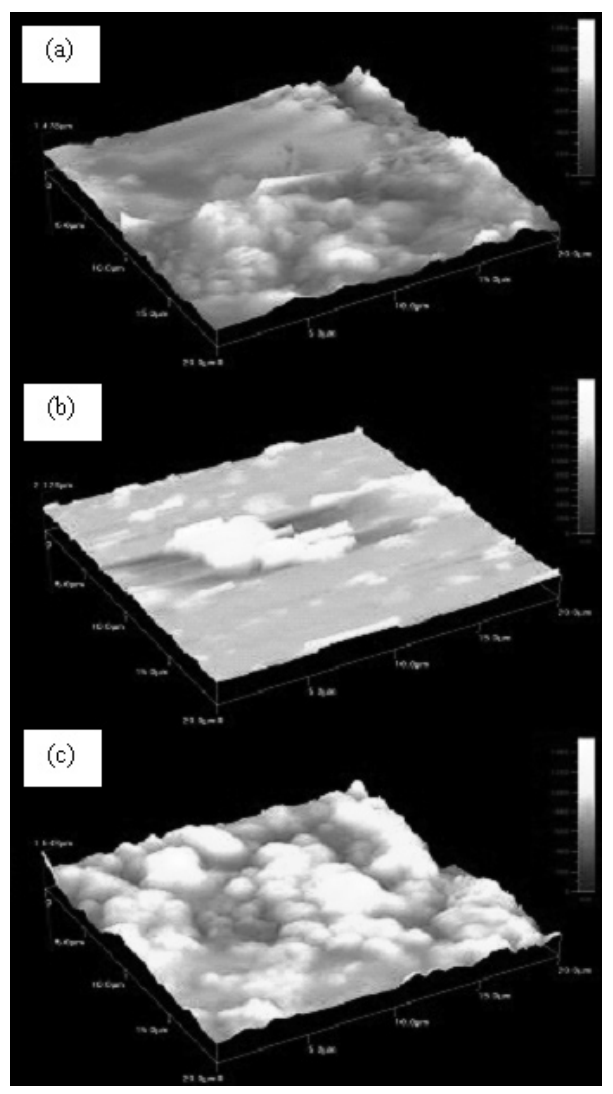

Fig. 6. Atomic force microscopy images of $\mathrm{Cu}_{4} \mathrm{SnS}_{4}$ thin films deposited at $50{ }^{\circ} \mathrm{C}$ in different $\mathrm{pH}$ solutions (a) $\mathrm{pH} 0.5$ (b) $\mathrm{pH} 1.0$ (c) $\mathrm{pH} 1.5$.
Fig. 7 shows the absorption spectra of $\mathrm{Cu}_{4} \mathrm{SnS}_{4}$ films at different $\mathrm{pH}$ values. The films show a gradually increasing absorbance throughout the visible region. The films grown at $\mathrm{pH} 1.5$ are thicker and have higher absorption characteristics. This response also associated with the fact that more polycrystalline $\mathrm{Cu}_{4} \mathrm{SnS}_{4}$ materials were formed at this $\mathrm{pH}$ value. Thus, $\mathrm{pH} 1.5$ is more preferable in the preparation of $\mathrm{Cu}_{4} \mathrm{SnS}_{4}$ films of better quality on ITO substrate.

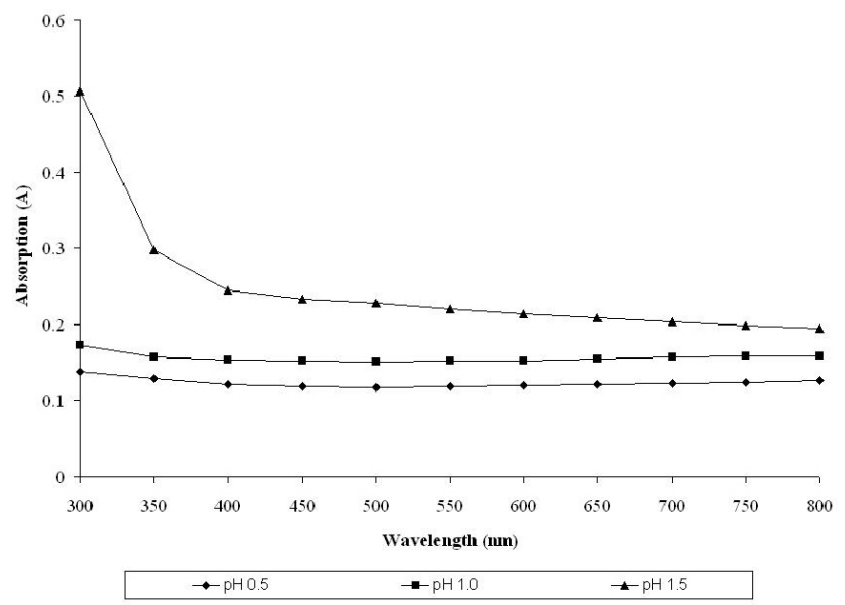

Fig. 7. Optical absorbance versus wavelength of the $\mathrm{Cu}_{4} \mathrm{SnS}_{4}$ films deposited at $50{ }^{\circ} \mathrm{C}$ in different $\mathrm{pH}$ solutions.

Fig. 8 indicates the different between photocurrent $\left(\mathrm{I}_{\mathrm{p}}\right)$ and darkcurrent $\left(\mathrm{I}_{\mathrm{d}}\right)$ for the films deposited at different $\mathrm{pH}$ of the chemical bath. The photoresponse for the films deposited at $\mathrm{pH} 0.5$ was the lowest because of least $\mathrm{Cu}_{4} \mathrm{SnS}$, crystallite formation. It is observed that the samples prepared at higher $\mathrm{pH}(\mathrm{pH}$ $1.5)$ values have the highest photoresponse activity.

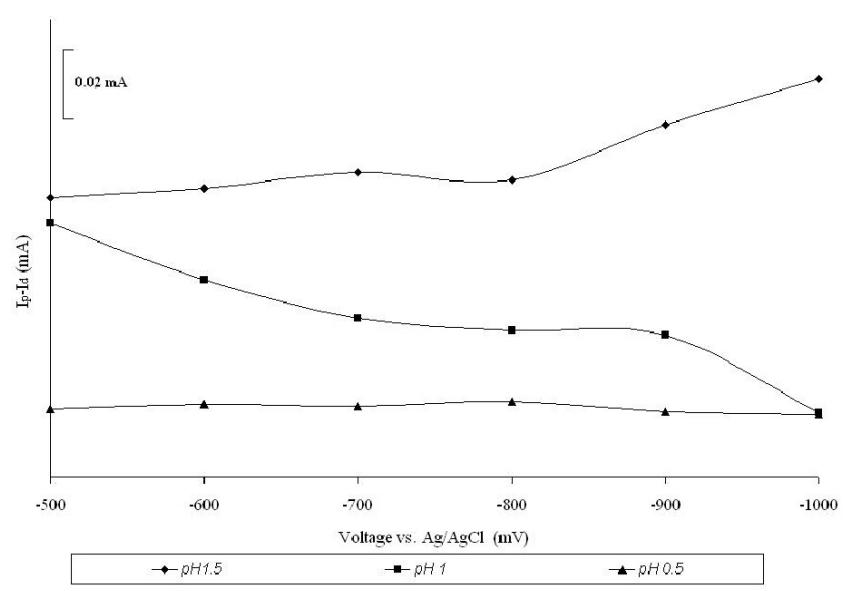

Fig. 8. Comparison of photosensitivity of the films deposited at $50{ }^{\circ} \mathrm{C}$ in different $\mathrm{pH}$ solutions.

Band gap energy and transition type can be derived from mathematical treatment of data obtained from optical absorbance versus wavelength with Stern relationship of near-edge absorption:

$$
A=\frac{\left[k\left(h v-E_{\mathrm{g}}\right)^{n / 2}\right.}{h v}
$$

where $v$ is the frequency, $h$ is the Planck's constant, $k$ equals a constant while $n$ carries the value of either 1 or 4 . The value of $n$ is 1 and 4 for the direct transition and indirect transition, respectively. The band gap $\left(\mathrm{E}_{\mathrm{g}}\right)$ could be obtained from a straight line plot of $(A h v)^{2 / n}$ as a function of $h v$. Extrapolation of the line to the base line, where the value of $(A h v)^{2 / n}$ is zero, will give $\mathrm{E}_{\mathrm{g}}$. The $(A h v)^{1 / 2}$ versus $h v$ plot is a straight line (Fig. 9) indicating that the energy band gap of $\mathrm{Cu}_{4} \mathrm{SnS}_{4}$ is direct and intercept on the $h v$ axis yield a band gap of $1.4 \mathrm{eV}$ for the film prepared in $50^{\circ} \mathrm{C}$ at $\mathrm{pH} 1.5$. 


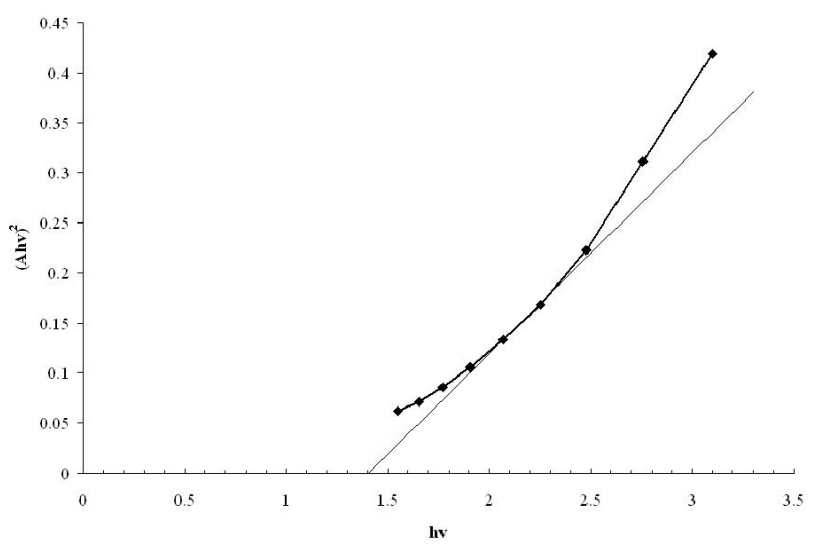

Fig. 9. Plot of $(A h v)^{2 / n}$ versus $h v$ when $\mathrm{n}=4$ for $\mathrm{Cu}_{4} \mathrm{SnS}_{4}$ films deposited at $50{ }^{\circ} \mathrm{C}$ in $\mathrm{pH} 1.5$.

\section{CONCLUSIONS}

$\mathrm{Cu}_{4} \mathrm{SnS}_{4}$ thin films have been chemically deposited on indium tin oxide substrates from aqueous solution containing $\mathrm{CuSO}_{4}, \mathrm{SnCl}_{2}, \mathrm{Na}_{2} \mathrm{~S}_{2} \mathrm{O}_{3}$ and $\mathrm{Na}_{2} \mathrm{EDTA}$. The thin films produced were found to be polycrystalline with orthorhombic structure. The X-ray diffraction pattern showed that the most intense peak at $2 \theta=30.2^{\circ}$ which belongs to (221) plane of $\mathrm{Cu}_{4} \mathrm{SnS}_{4}$. The films deposited at $50{ }^{\circ} \mathrm{C}$ were found to have the best photoresponse activity and smaller crystal size. At $\mathrm{pH}$ 1.5, the film showed well-covered entire substrate surface and the highest absorption values in AFM and optical study, respectively. Deposition at $50{ }^{\circ} \mathrm{C}$ with $\mathrm{pH} 1.5$ is the optimum condition to prepare good quality thin films under the current condition. The bandgap value was found to be $1.4 \mathrm{eV}$ with direct transition. The photoresponse in the cathodic region indicate the p-type semiconductor.

\section{ACKNOWLEDGEMENTS}

The authors would like to thank the Department of Chemistry, Universiti Putra Malaysia for the provision of laboratory facilities and MOSTI for the National Science Fellowship (NSF).

\section{REFERENCES}

1. A.M. Ali, T. Inokuma, S. Hasegawa, Appl. Surf. Sci. 253, 1198, (2006).

2. R.A. Berrigan, N. Maung, S.J.C. Irvine, D.J. Cole-Hamilton, D.J. Ellis, J. Cryst. Growth. 195, 718, (1998).

3. A. Timoumi, H. Bouzouita, M. Kanzari, B. Rezig, Thin Solid Films. 480481, 124, (2005).

4. H. Khallaf, I.O. Oladeji, L. Chow, Thin Solid Films. 516, 5967, (2008).

5. S. Armstrong, P.K. Datta, R.W. Miles, Thin Solid Films. 403-404, 126, (2002).

6. L. Barkat, N. Hamdadou, M. Morsli, A. Khelil, J.C. Bernede, J. Cryst. Growth. 297, 426, (2006).

7. S. Beyhan, S. Suzer, F. Kadirgan, Sol. Energy Mater. Sol. Cells. 91, 1922, (2007).

8. C. Gautier, G. Breton, M. Nouaoura, M. Cambon, S. Charar, M. Averous, Thin Solid Films. 315, 118, (1998).

9. I. Oja, M. Nanu, A. Katerski, M. Krunks, A. Mere, J. Raudoja, A. Goossens, Thin Solid Films. 480-481, 82, (2005).

10. A. Gupta, V. Parikh, A.D. Compaan, Sol. Energy Mater. Sol. Cells. 90 , 2263, (2006)

11. C. Gumus, C. Ulutas, Y. Ufuktepe, Opt. Mater. 29, 1183, (2007).

12. M. Ristov, G. Sinadinovski, M. Mitreski, M. Ristova, Sol. Energy Mater. Sol. Cells. 69, 17, (2001).

13. Z. Zainal, N. Saravanan, K. Anuar, M.Z. Hussein, W.M.M. Yunus, Mater. Sci. Eng. B. 107, 181, (2004).

14. M. Simurda, P. Nemec, P. Formanek, I. Nemec, Y. Nemcova, P. Maly, Thin Solid Films. 511-512, 71, (2006).

15. S. Messina, M.T.S. Nair, P.K. Nair, Thin Solid Films. 515, 5777, (2007).

16. S. Seghaier, N. Kamoun, R. Brini, A.B. Amara, Mater. Chem. Phys. 97, $71,(2006)$.

17. R.S. Mane, C.D. Lokhande, Thin Solid Films. 304, 56, (1997).

18. K. Bindu, C.S. Kartha, K.P. Vijayakumar, T. Abe, Y. Kashiwaba, Sol. Energy Mater. Sol. Cells. 79, 67, (2003).

19. R.B. Kale, C.D. Lokhande, R.S. Mane, S.H. Han, Appl. Surf. Sci. 253, 3109, (2007).

20. P.S. Sonawane, P.A. Wani, L.A. Patil, T. Seth, Mater. Chem. Phys. 84, $221,(2004)$ 